http:/www.journals.zu.edu.eg/journalDisplay.aspx?Journalld=1\&queryType=Master

\title{
EFFECT OF NITROGEN, PHOSPHORUS AND IRON FERTILIZATION ON PRODUCTVITY AND MINERAL CONTENTS OF WHEAT
}

\author{
Ashraf A.M. Habib ${ }^{1 *}$, A.E. El-Sherbieny ${ }^{2}$, S.M. Dahdouh ${ }^{2}$, M.S. Dahdoh ${ }^{1}$ and A.S. Metwaly ${ }^{2}$ \\ 1. Microbiol. and Soil Fert. Dept. Des. Res. Cent., Cairo, Egypt \\ 2. Soil Sci. Dept., Fac. Agric., Zagazig Univ., Egypt
}

Received: 02/10/2017 ; Accepted: 24/10/2017

\begin{abstract}
Wheat fields in Egypt are spatially variable as to soil fertility and crop productivity. The general objective of this study is to determine the relationships between yield, mineral content of wheat with $\mathrm{N}, \mathrm{P}$ and iron foliar spray rates using the regression analysis of yield data. The study was carried out using $\mathrm{N}$ application $\left(190,285\right.$ and $\left.380 \mathrm{Kg} \mathrm{N} \mathrm{ha}^{-1}\right), \mathrm{P}$ application $\left(0,15,31\right.$ and $\left.47 \mathrm{Kg} \mathrm{P} \mathrm{ha}^{-1}\right)$ and iron foliar spray (without, mineral iron and chelated iron at $0.2 \mathrm{gl}^{-1}$ ). Wheat (Triticum aestivum, Giza 168 cultivar) was grown at research station of the Desert Research Center, El Quntra Sharq, Eastren North Sinai, Egypt in the 2015-2016 season. The highest grain and straw yields were obtained under $285 \mathrm{Kg} \mathrm{N}+$ chelated iron and $31 \mathrm{Kg} \mathrm{P} \mathrm{ha}^{-1}$. The highest wheat grain nitrogen uptake was obtained under $285 \mathrm{Kg} \mathrm{N}+$ chelated iron and $31 \mathrm{Kg} \mathrm{P}^{-1}$. The highest $\mathrm{N}$ uptake by wheat straw was obtained under $285 \mathrm{Kg} \mathrm{N}+$ chelated iron and $47 \mathrm{Kg} \mathrm{P} \mathrm{ha}^{-1}$. The highest $\mathrm{P}$ uptake in grains was obtained under $380 \mathrm{~kg} \mathrm{~N}^{-1}+$ mineral iron and $31 \mathrm{Kg} \mathrm{P} \mathrm{ha}^{-1}$. The highest $\mathrm{P}$ uptake in straw was obtained under $285 \mathrm{Kg} \mathrm{N} \mathrm{ha}^{-1}+$ chelated iron and $31 \mathrm{Kg} \mathrm{P}^{-1}$. The highest Fe uptake in grains was obtained under $285 \mathrm{Kg} \mathrm{N} \mathrm{ha}^{-1}+$ mineral iron and $47 \mathrm{Kg} \mathrm{P} \mathrm{ha}^{-1}$. The highest $\mathrm{Fe}$ uptake in straw was obtained under $285 \mathrm{Kg} \mathrm{N}^{-1}+$ mineral iron and $47 \mathrm{Kg} \mathrm{P} \mathrm{ha}^{-1}$.
\end{abstract}

Key words: Grain yield, N and P fertilization, iron foliar, wheat.

\section{INTRODUCTION}

Wheat is the first strategic food crop in Egypt. It has maintained its position during that time as the basic staple food for Egyptians. Wheat straw is an important fodder for animals in Egypt. Wheat plants are sometimes exposed to drought stress at different periods of growth. A possible approach to minimize drought stress that induces crop losses, is foliar application with some chemical desiccant on wheat plants.

Nitrogen is a constituent of proteins, enzymes, coenzymes, nucleic acids, phytochromes and chlorophyll. It plays an important role in the biochemical processes of the plant (Grundon et al., 1987). Therefore, it is one of the most required nutrients for wheat. Phosphorus is an essential nutrient required for the growth of wheat with a key role in the structure of cell membranes, DNA and RNA, photosynthesis and respiration (Grant et al., 2001). Plants during their initial stage of growth, need adequate $\mathrm{P}$ due to its role in cell division. Thus symptoms of $\mathrm{P}$ deficiency are particularly evident during plant early growth stages (Grundon et al., 1987). Mild $\mathrm{P}$ deficiency causes stunting while severe deficiency darkens leaves, causes older leaves to brown and die off and reduces tillering, head and grain numbers (Grundon et al., 1987).

Iron is most important for respiration and photosynthesis processes. It plays a vital role in many plant processes such as chlorophyll development, energy transfer, enzymes, proteins synthesis, and nitrogen fixation as well as nucleic acid metabolism (Havlin et al., 2014). The main objective of the current study is to

\footnotetext{
* Corresponding author: Tel. : +201009678648

E-mail address: aea_2013sc@yahoo.com
} 
asse and evaluate the effect of nitrogen, phosphorus and $\mathrm{Fe}$ on soil and wheat plant regarding plant growth and contents of elements especially $\mathrm{N}, \mathrm{P}, \mathrm{K}$ and Fe.

\section{MATERIALS AND METHODS}

A field experiment was conducted during season of 2015/2016 at Desert Research Station, El Quntra Sharq, Eastern North Sinai, Egypt. Table 1 shows the properties of the soil where the experiment was conducted. The objective was to study the effect of N, P and Fe fertilization on the yield of wheat (Triticum aestivum, Giza 168 cultivar) as well as uptake of nutrients and their content in soil. The treatments were conducted in three replicates using split- split design.

Three rates of $\mathrm{N}$ were used as ammonium sulphate $(20 \% \mathrm{~N})$, i.e., $190\left(\mathrm{~N}_{1}\right), 285\left(\mathrm{~N}_{2}\right)$ and $380 \mathrm{Kg} \mathrm{N} \mathrm{ha}^{-1}\left(\mathrm{~N}_{3}\right)$ added in 3 splits 25,50 and $25 \%$ after 30, 60 and 90 days from sowing, respectively. Four rates of $\mathrm{P}$ as ordinary superphosphate $(6.8 \% \mathrm{P})$, i.e., $0\left(\mathrm{P}_{0}\right), 15\left(\mathrm{P}_{1}\right), 31$ $\left(\mathrm{P}_{2}\right)$ and $47 \mathrm{Kg} \mathrm{P}$. ha ${ }^{-1} .\left(\mathrm{P}_{3}\right)$ were added 15 days before cultivation during soil preparates. Two sources of iron were used as foliar spray $(\mathrm{Fe}$ sulphat and $\mathrm{Fe}$ chelate) $\mathrm{FeSO}_{4} \cdot 7 \mathrm{H}_{2} \mathrm{O}(20 \% \mathrm{Fe})$ and chelated Fe-IDHA (13\% Fe) spray solution was $2 \mathrm{~g} \mathrm{l}^{-1}$ spray was done three times , i.e., 30, 60 and 90 days after seeding. Irrigation was done weekly. Plant samples were taken at five stages after 30,60, 90, 120 and 150 days maturity stage (at harvesting time) and the end of the experiment samples of plant materials were ground and wet digested with a mixture of concentrated sulphoric and perchloric acids for nutrient determination according to Thomas et al. (1967) and Brennar and Mulvaey (1982). Samples of soil from the depths of 0-30 and 30$60 \mathrm{~cm}$ were taken at harvest to determine soil available N, P and K. Determination of the physical and chemical properties of the investigated soil samples prior to at the end of the experiment were performed according to the standard methods outlined by Black et al. (1965). Available N was extracted by $2 \mathrm{MKCl}$ and determined by microkjeldahl according to Chapman and Pratt (1961). Available K was extracted by $1 \mathrm{~N} \mathrm{NH}_{4} \mathrm{OAC}$ and available $\mathrm{P}$ was extracted by $0.5 \mathrm{M} \mathrm{NaHCO}$ solution at $\mathrm{pH} 8.5$ (Olsen et al., 1954) and determined using ascorbic acid and ammonium molybdate according to Holman and Elliott (1983). Iron in plant was determined using Atomic Absorption Spectrophotometer.

\section{RESULTS AND DISCUSSION}

\section{Wheat Yield}

Wheat yield at different stages under nitrogen, Phosphorus fertilization and foliar spray of iron is recorded in Fig. 1. There were positive effects of nitrogen; phosphorus fertilization and iron spray addition on yield of wheat ranged between 547 and $9229 \mathrm{Kg}^{-h^{-1}}$ at tillring and ripening stages, respectively. The lowest yield of wheat plant was obtained at tillering. The highest wheat yield was obtained at ripening. The indicated results that nitrogen, phosphorus and iron addition increased yield at all growth stages valued as $261,1037,1107$ and $1588 \%$ at tillering, jointing, booting, heading and ripening, respectively.

At harvest, wheat yield under nitrogen, phosphorus and iron recorded in Table 2. There were positive effects of nitrogen; phosphorus fertilization and iron spray. The grain yield of wheat ranged between 1.76 and $4.81 \mathrm{Mg} \mathrm{ha}^{-1}$. The lowest grain yield of wheat was obtained by $190 \mathrm{Kg} \mathrm{N} \mathrm{ha}{ }^{-1}$. The highest wheat grain yield was obtained under $285 \mathrm{Kg} \mathrm{N}+31 \mathrm{Kg} \mathrm{P} \mathrm{ha}^{-1}$ and chelated iron spray.

Increasing nitrogen addition from 190 to 285 and $380 \mathrm{Kg} \mathrm{N} \mathrm{ha}^{-1}$ increased grain yield by 32.4 and $32.8 \%$, respectively. For phosphorus addition, the results indicated that increasing phosphorus addition from 0 to 15,31 or $47 \mathrm{Kg} \mathrm{P}$ ha $^{-1}$ increased grain yield $24.4,55.8$ and $33.5 \%$, respectively. For iron sprays, the results indicated that mineral iron and chelated iron increased grain yield by 29.21 and $33.33 \%$, respectively.

The straw yield of wheat ranged between 3.32 and $9.15 \mathrm{Mg} \mathrm{ha}^{-1}$. The lowest straw yield of wheat plant was obtained by $190 \mathrm{Kg} \mathrm{N} \mathrm{ha}{ }^{-1}$ which did not receive phosphorus or iron spray. The highest wheat straw yield was obtained under $285 \mathrm{Kg} \mathrm{N}+31 \mathrm{Kg} \mathrm{P}$ ha $^{-1}$ and chelated iron. For nitrogen addition, the results indicated that increasing nitrogen addition from 190 to 285 or $380 \mathrm{Kg} \mathrm{N} \mathrm{ha}^{-1}$, increased straw yield by 31.7 and $36.6 \%$, respectively. For phosphorus addition, 
Table 1. Some physical and chemical characteristics of the experimental site before cultivation

\begin{tabular}{|c|c|}
\hline Properties & Value \\
\hline \multicolumn{2}{|l|}{ Physical properties } \\
\hline Coarse sand & 64.1 \\
\hline Fine sand & 26.4 \\
\hline Silt & 2.7 \\
\hline Clay & 6.8 \\
\hline Texture & Sand \\
\hline \multicolumn{2}{|c|}{ Chemical properties } \\
\hline pH (1:5) Suspension. & 8.6 \\
\hline EC $(1: 5)$ dS. $\mathrm{m}^{-1}$ soil extract & 0.61 \\
\hline \multicolumn{2}{|c|}{ Avilable mg kg ${ }^{-1}$} \\
\hline $\mathrm{N}$ & 42 \\
\hline$P$ & 3.45 \\
\hline K & 95 \\
\hline \multicolumn{2}{|c|}{ Soluble ions mmole $\mathrm{kg}^{-1}$ soil } \\
\hline $\mathrm{Mg}^{++}$ & 0.605 \\
\hline $\mathrm{Ca}^{++}$ & 0.876 \\
\hline $\mathrm{Na}^{+}$ & 4.340 \\
\hline $\mathrm{K}^{+}$ & 0.230 \\
\hline $\mathrm{SO}_{4}^{--}$ & 0.281 \\
\hline $\mathrm{CO}_{3}^{--}$ & - \\
\hline $\mathrm{HCO}_{3}^{-}$ & 1.77 \\
\hline$\overline{\mathrm{Cl}^{-}}$ & 4.00 \\
\hline
\end{tabular}

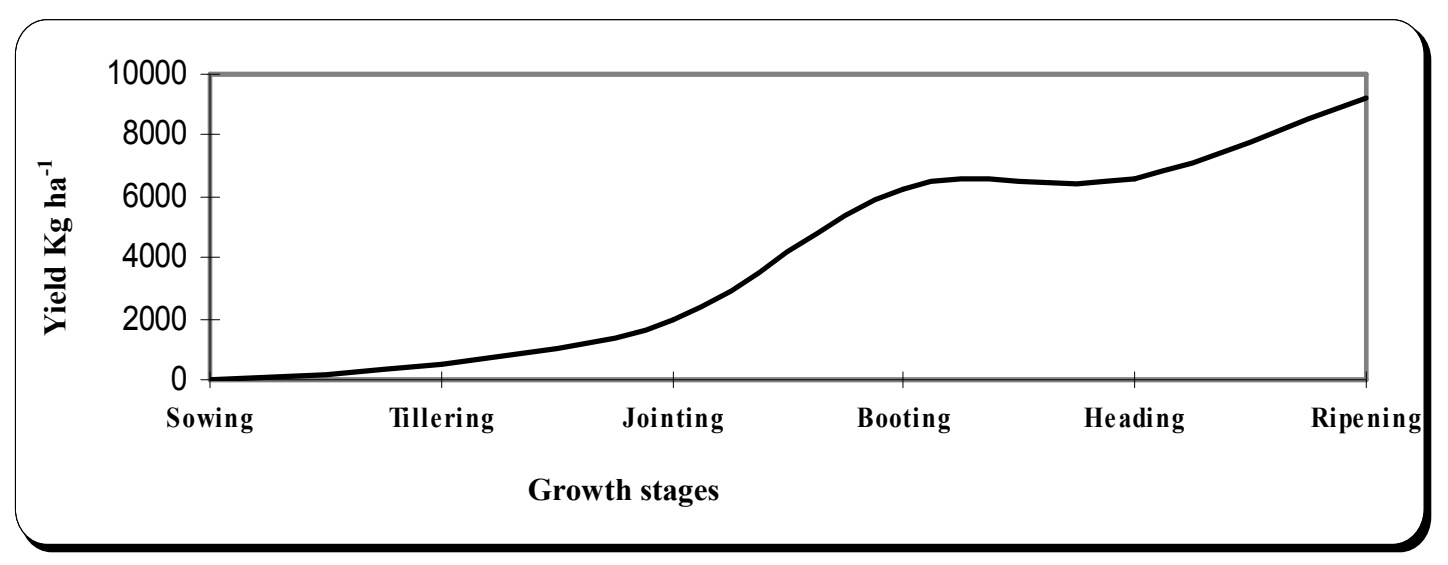

Fig. 1. Yield $\left(\mathrm{Kg} \mathrm{ha}^{-1}\right)$ at different growth stages 
Table 2. Grain and straw yields $\left(\mathrm{Mg} \mathrm{ha}^{-1}\right)$ as influenced by application of nitrogen, phosphorus fertilization and iron foliar spray

\begin{tabular}{|c|c|c|c|c|c|c|c|c|c|c|c|}
\hline \multirow{3}{*}{$\begin{array}{l}\text { Nitrogen rate } \\
\left(\mathrm{kg} \mathrm{ha}^{-1}\right) \\
\text { (A) }\end{array}$} & \multirow{3}{*}{$\begin{array}{c}\text { Iron } \\
\text { sources } \\
\text { (C) }\end{array}$} & \multicolumn{10}{|c|}{ Phosphorus rate $\left(\mathrm{kg} \mathrm{ha}^{-1}\right)(\mathrm{B})$} \\
\hline & & $\mathbf{0}$ & 15 & 31 & 47 & Mean & $\mathbf{0}$ & 15 & 31 & 47 & Mean \\
\hline & & \multicolumn{5}{|c|}{ Grain yield } & \multicolumn{5}{|c|}{ Straw yield } \\
\hline & Without & 1.76 & 2.44 & 2.77 & 2.49 & 2.37 & 3.32 & 4.25 & 5.29 & 5.20 & 4.52 \\
\hline \multirow[t]{2}{*}{190} & Min.Fe & 2.01 & 2.78 & 3.42 & 2.84 & 2.76 & 3.70 & 4.61 & 6.10 & 5.56 & 4.99 \\
\hline & Chel.Fe & 2.06 & 2.87 & 3.38 & 2.99 & 2.83 & 3.81 & 4.88 & 6.17 & 5.75 & 5.15 \\
\hline \multirow[t]{2}{*}{ Mean } & & 1.94 & 2.70 & 3.19 & 2.77 & 2.65 & 3.61 & 4.58 & 5.85 & 5.50 & 4.89 \\
\hline & Without & 2.15 & 2.49 & 3.41 & 2.61 & 2.67 & 4.08 & 4.46 & 5.83 & 5.39 & 4.94 \\
\hline \multirow[t]{2}{*}{285} & Min.Fe & 2.97 & 3.77 & 4.69 & 3.95 & 3.85 & 5.66 & 6.11 & 9.14 & 7.41 & 7.08 \\
\hline & Chel.Fe & 3.24 & 3.89 & 4.81 & 4.08 & 4.01 & 6.07 & 6.28 & 9.15 & 7.73 & 7.31 \\
\hline \multirow[t]{2}{*}{ Mean } & & 2.79 & 3.38 & 4.30 & 3.55 & 3.51 & 5.27 & 5.62 & 8.04 & 6.84 & 6.44 \\
\hline & Without & 2.68 & 2.68 & 3.77 & 2.74 & 2.97 & 4.24 & 5.25 & 7.49 & 6.68 & 5.92 \\
\hline \multirow[t]{2}{*}{380} & Min.Fe & 2.71 & 3.57 & 4.44 & 4.21 & 3.73 & 5.57 & 6.32 & 8.79 & 7.55 & 7.06 \\
\hline & Chel.Fe & 3.04 & 3.65 & 4.46 & 4.27 & 3.86 & 5.34 & 6.45 & 8.79 & 7.69 & 7.07 \\
\hline \multirow[t]{5}{*}{ Mean } & & 2.81 & 3.30 & 4.22 & 3.74 & 3.52 & 5.05 & 6.01 & 8.36 & 7.31 & 6.68 \\
\hline & & \multicolumn{10}{|c|}{ Mean of Fe treatment } \\
\hline & Without & 2.20 & 2.54 & 3.32 & 2.61 & 2.67 & 3.88 & 4.65 & 6.20 & 5.76 & 5.12 \\
\hline & Min.Fe & 2.56 & 3.37 & 4.18 & 3.67 & 3.45 & 4.98 & 5.68 & 8.01 & 6.84 & 6.38 \\
\hline & Chel.Fe & 2.78 & 3.47 & 4.22 & 3.78 & 3.56 & 5.07 & 5.87 & 8.04 & 7.06 & 6.51 \\
\hline \multirow[t]{2}{*}{ Mean } & & 2.51 & 3.13 & 3.91 & 3.35 & 3.22 & 4.64 & 5.40 & 7.42 & 6.55 & 6.00 \\
\hline & & \multicolumn{2}{|l|}{$A=0.086$} & \multicolumn{2}{|c|}{$\mathrm{AB}=0.089$} & & \multicolumn{2}{|c|}{$\mathrm{A}=0.104$} & \multicolumn{3}{|c|}{$\mathrm{AB}=0.208$} \\
\hline \multirow{3}{*}{$\begin{array}{l}\text { LSD } \\
(0.05)\end{array}$} & & \multicolumn{2}{|l|}{$\mathrm{B}=0.052$} & \multicolumn{2}{|c|}{$\mathrm{BC}=0.161$} & & \multicolumn{2}{|c|}{$\mathrm{B}=0.121$} & \multicolumn{3}{|c|}{$\mathrm{BC}=0.195$} \\
\hline & & \multicolumn{2}{|l|}{$\mathrm{C}=0.81$} & \multicolumn{2}{|c|}{$\mathrm{AC}=0.139$} & & \multicolumn{2}{|c|}{$\mathrm{C}=0.098$} & \multicolumn{3}{|c|}{$\mathrm{AC}=0.169$} \\
\hline & & \multicolumn{2}{|c|}{$\mathrm{ABC}=0.279$} & & & & \multicolumn{2}{|c|}{$\mathrm{ABC}=0.338$} & & & \\
\hline
\end{tabular}

the results indicated that increasing phosphorus addition from 0 to 15,31 or $47 \mathrm{Kg} \mathrm{P} \cdot \mathrm{ha}^{-1}$, increased straw yield by $16.4,59.9$ and $41.2 \%$, respectively. For iron spray, mineral iron and chelated iron increased straw yield by 24.61 and $27.15 \%$, respectively. The above results are in agreement with those obtained by Jamal and Chaudhary (2007), Silwana et al. (2007), Khan et al. (2009) and Betric et al. (2006).

\section{Nitrogen Uptake by Wheat}

The wheat nitrogen uptake at different stages under nitrogen, phosphorus fertilization and $\mathrm{Fe}$ foliar spray are shown in Fig. 2. There were positive effects of nitrogen; phosphorus fertilization and iron spray. The nitrogen uptake by wheat ranged between 7.57 and $131.83 \mathrm{Kg} \mathrm{ha}^{-1}$ at tillring and ripening stages, respectively. The lowest nitrogen uptake was obtained at tillering 


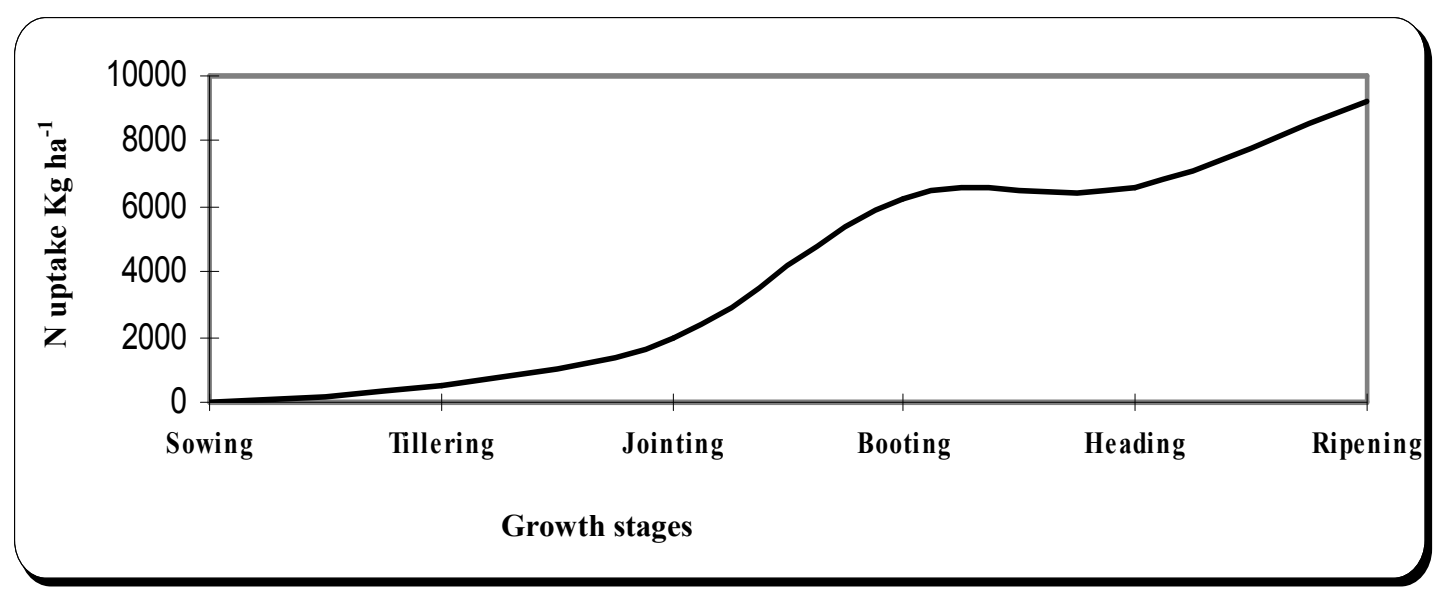

Fig. 2. Nitrogen uptake $\left(\mathrm{Kg} \mathrm{ha}^{-1}\right)$ at different growth stages

stage. The highest wheat nitrogen uptake was obtained at ripening stage. The results indicated that increasing nitrogen, phosphorus and iron increased nitrogen uptake at tillering, jointing, booting, heading and ripening as averaged 337, 731,1239 and $1641 \%$, respectively.

$\mathrm{N}$ uptake at ripening stages is shown in Fig. 2. There were positive effects of applying nitrogen; phosphorus and iron. The $\mathrm{N}$ uptake in grains ranged between 48.13 and $125.79 \mathrm{Kg} \mathrm{ha}^{-1}$ (Table 3). The lowest was obtained by $190 \mathrm{Kg} \mathrm{N}$ $\mathrm{ha}^{-1}$ and the highest was obtained by $285 \mathrm{Kg} \mathrm{N}+$ $31 \mathrm{Kg} \mathrm{P} \mathrm{ha}{ }^{-1}+$ chelated iron spray.

For nitrogen addition, the results indicated that increasing nitrogen addition from 190 to 285 or $380 \mathrm{~kg} \mathrm{~N} \mathrm{ha}^{-1}$ increased grain nitrogen uptake by averages of 44.4 and $35.1 \%$, respectively. For phosphorus addition, the results indicated that increasing phosphorus addition from 0 to 15,31 or $47 \mathrm{Kg} \mathrm{P} \mathrm{ha}^{-1}$ increased grain nitrogen uptake by an average of $25.8,49.4$ and $39.9 \%$, respectively. For iron sprays either mineral iron spray or chelated iron spray; the results indicated that mineral iron or chelated iron increased grain nitrogen uptake by 34.35 and 35.28 , respectively.

The straw nitrogen uptake of wheat ranged between 27.92 and $89.23 \mathrm{Kg} \mathrm{ha}^{-1}$. The lowest was obtained by $190 \mathrm{Kg} \mathrm{N} \mathrm{ha}^{-1}$ without addition both of phosphorus and iron and the highest was obtained under $285 \mathrm{Kg} \mathrm{N}+47 \mathrm{Kg} \mathrm{P} \mathrm{ha}{ }^{-1}+$ chelated iron. For nitrogen addition, the results indicated that increasing nitrogen addition from 190 to 285 or $380 \mathrm{Kg} \mathrm{N} \mathrm{ha}^{-1}$ increased straw nitrogen uptake by averages of 48.5 and $48.8 \%$, respectively. For phosphorus addition, the results indicated that increasing phosphorus addition from 0 to 15,31 or $47 \mathrm{Kg} \mathrm{P} \mathrm{ha}{ }^{-1}$, increased straw nitrogen uptake by averages of $12.7,30.3$ and $38.02 \%$, respectively. For iron sprays results indicated that mineral iron and chelated iron increased straw nitrogen uptake by 26.70 and 37.49 , respectively. The above results agree with those obtained by Betric et al. (2006), Kegang (2005), Jamal and Chaudhary (2007) and Khan et al. (2009).

\section{Phosphorus Uptake by Wheat}

Values of phosphorus uptake are recorded in Fig. 3. There were positive effects of nitrogen; phosphorus fertilization and iron spray. The phosphorus uptake of wheat ranged between 1.28 and $16.49 \mathrm{Kg} \mathrm{ha}^{-1}$. The lowest phosphorus uptake of wheat plant was obtained at tillering stage. The highest wheat phosphorus uptake was obtained at ripening stage. Increasing nitrogen, phosphorus and iron addition increased phosphorus uptake by advancing growth stages at tillering, jointing, booting, heading and ripening by averages of $176.56,358.59,528.91$ and $1188.28 \%$, respectively. 
Table 3. Grain and straw nitrogen uptake $\left(\mathrm{Kg} \mathrm{ha}^{-1}\right)$ as influenced by application of nitrogen, phosphorus fertilization and iron foliar spray

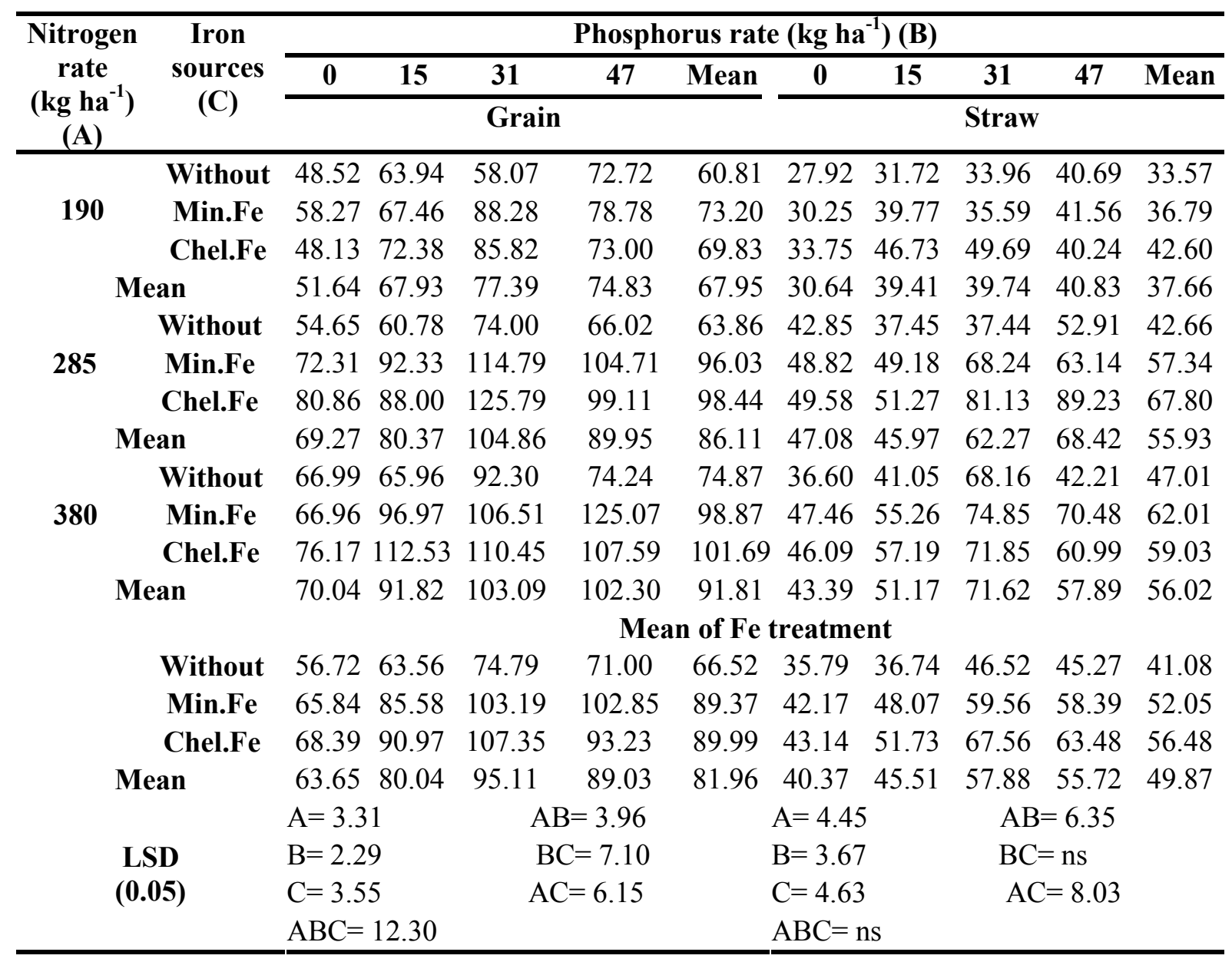

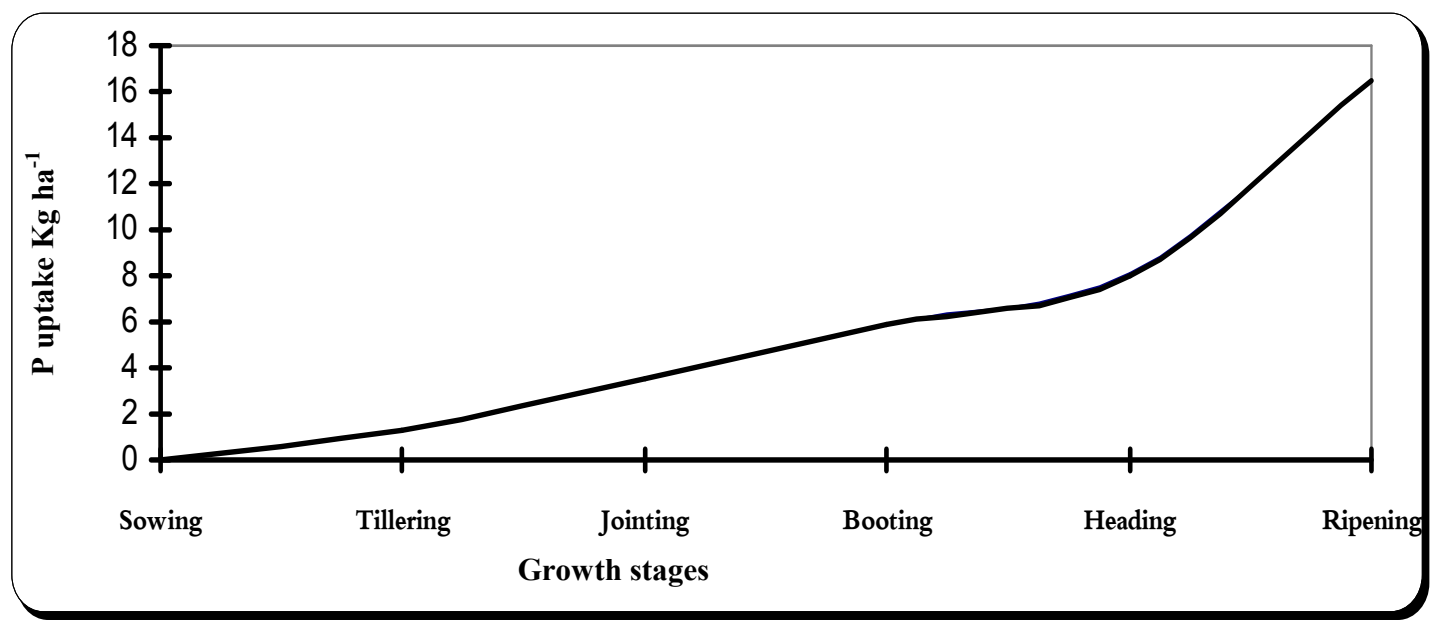

Fig. 3. Phosphorus uptake $\left(\mathrm{Kg} \mathrm{ha}^{-1}\right)$ at different growth stages 
$\mathrm{P}$ uptake at various stages of wheat growth is shown in Fig. 3 phosphorus uptake in grains and straw is shown in Table 4. Phosphorus uptake in grains ranged between 9.08 and $25.46 \mathrm{Kg} \mathrm{ha}^{-1}$. The lowest was obtained by $190 \mathrm{Kg} \mathrm{N} \mathrm{ha}^{-1}$. The highest was obtained under $380 \mathrm{Kg} \mathrm{N} \mathrm{ha}^{-1}+31$ $\mathrm{Kg} \mathrm{P} . \mathrm{ha}^{-1}+$ mineral iron. For nitrogen addition, the results indicated that increasing nitrogen addition from 190 to 285 or $380 \mathrm{Kg} \mathrm{N} \mathrm{ha}$ increased grain phosphorus uptake by averages of 5.6 and $24.5 \%$, respectively. For phosphorus addition, the results indicated that increasing phosphorus addition from 0 to 15,31 or $47 \mathrm{Kg}$ P.ha ${ }^{-1}$, increased grain phosphorus uptake by averages of $19.6,57.4$ and $45.7 \%$, respectively. For iron sprays the results indicated that using mineral iron and chelated iron increased grain phosphorus uptake by 36.36 and $33.46 \%$, respectively.

$\mathrm{P}$ uptake in straw ranged between 2.76 and $11.64 \mathrm{Kg} \mathrm{ha}^{-1}$. The lowest straw was obtained by $190 \mathrm{Kg} \mathrm{N} \mathrm{ha}^{-1}$. The highest was obtained under $285 \mathrm{Kg} \mathrm{N} \mathrm{ha}^{-1}+31 \mathrm{Kg} \mathrm{P} \mathrm{ha}^{-1}$ and chelated iron. For nitrogen addition, the results indicated that increasing nitrogen addition from 190 to 285 or $380 \mathrm{Kg} \mathrm{N} \mathrm{ha}^{-1}$ increased straw phosphorus uptake averages of 35.8 and $37.9 \%$, respectively. For phosphorus addition, the results indicated that increasing phosphorus addition from 0 to 15,31 or $47 \mathrm{Kg} \mathrm{P} . \mathrm{ha}^{-1}$ increased straw phosphorus uptake by averages of $8.9,85.2$ and $49.6 \%$, respectively. For iron sprays the results indicated that mineral iron and chelated iron increased straw phosphorus uptake by 31.37 and $33.68 \%$, respectively. The above results agreed with those obtained by Betric et al. (2006) and Khan et al. (2009).

\section{Potassium Uptake by Wheat}

The wheat potassium uptake under nitrogen, phosphorus and iron spray recorded in Fig. 4 and Table 5. Potassium uptake ranged between 12.08 and $74.73 \mathrm{Kg} \mathrm{ha}^{-1}$. The lowest was obtained at tillering stage. The highest wheat was obtained at ripening stage. Applying nitrogen, phosphorus and iron increased $\mathrm{K}$ uptake at stages of tillering, jointing, booting, heading and ripening by averages of $268.79,537.75,1026.49$ and $518.63 \%$, respectively. There were positive effects of nitrogen; phosphorus fertilization and iron spray addition. The grain potassium uptake of wheat ranged between 8.53 and $26.00 \mathrm{~kg} \cdot \mathrm{ha}^{-1}$.
The lowest grain potassium uptake of wheat plant was obtained by $380 \mathrm{~kg} \mathrm{~N} \mathrm{ha}^{-1}$. The highest wheat grain potassium uptake was obtained under $285 \mathrm{~kg} \mathrm{~N} \mathrm{ha}^{-1}+31 \mathrm{Kg} \mathrm{P} \mathrm{ha}^{-1}+$ chelated iron spray. Increasing nitrogen addition from 190 to 285 or $380 \mathrm{~kg} \mathrm{~N}^{-1}$ increased grain potassium uptake br averages of 18.7 and $28.4 \%$, respectively.

Increasing phosphorus addition from 0 to 15 , 31 or $47 \mathrm{~kg} \mathrm{P} \mathrm{ha}^{-1}$ increased grain potassium uptake by averages of $37.7,89.0$ and $69.1 \%$, respectively. Mineral iron and chelated iron increased grain potassium uptake by 33.05 and $22.14 \%$, respectively.

The straw potassium uptake of wheat ranged between 27.69 and $104.72 \mathrm{~kg} \mathrm{ha}^{-1}$. The lowest was obtained by $190 \mathrm{~kg} \mathrm{~N}^{-1}$. The highest was obtained under $285 \mathrm{~kg} \mathrm{~N} \mathrm{ha}^{-1}+31 \mathrm{Kg} \mathrm{P} \mathrm{ha}^{-1}+$ chelated iron spray. For Nitrogen addition, the results indicated that increasing nitrogen addition from 190 to 285 and $380 \mathrm{~kg} \mathrm{~N}^{-1}$ increased straw potassium uptake by averages of 53.1 and $72.9 \%$, respectively.

For phosphorus addition, the results indicated that increasing phosphorus addition from 0 to 15,31 or $47 \mathrm{Kg} \mathrm{P}$ ha ${ }^{-1}$ increased straw potassium uptake by averages of $14.3,86.7$ and $48.5 \%$, respectively. For iron sprays the results indicated that using mineral iron and chelated iron increased straw potassium uptake by 22.21 and $25.11 \%$, respectively.

\section{Iron Uptake by Wheat}

The wheat iron uptake is shown in Table 6 . There were positive effects of nitrogen phosphorus fertilization and iron spray. The grain iron uptake of wheat ranged between 0.02 and $0.80 \mathrm{Kg} \cdot \mathrm{ha}^{-1}$. The lowest grain iron uptake of wheat plant was obtained by $190 \mathrm{Kg} \mathrm{N} \mathrm{ha}^{-1}$. The highest wheat grain iron uptake was obtained under $285 \mathrm{Kg} \mathrm{N}^{-1}+31 \mathrm{Kg} \mathrm{P} \mathrm{ha}^{-1}$ and mineral iron. For nitrogen addition, the results indicated that increasing nitrogen addition from 190 to 285 and $380 \mathrm{Kg} \mathrm{N} \cdot \mathrm{ha}^{-1}$ increased grain iron uptake by averages of 110.5 and $42.11 \%$, respectively. For phosphorus addition, the results indicated that increasing phosphorus addition from 0 to 15,31 or $47 \mathrm{Kg}$ P.ha ${ }^{-1}$ increased grain iron uptake by an average of $56.25,168.75$ and $100.0 \%$, respectively. Using mineral iron and chelated iron increased grain iron uptake by averages of 514 and $424 \%$, respectively. 
Table 4. Grain and straw phosphorus uptake $\left(\mathrm{Kg} \mathrm{ha}^{-1}\right)$ as influenced by application of nitrogen, phosphorus fertilization and iron foliar spray

\begin{tabular}{|c|c|c|c|c|c|c|c|c|c|c|c|}
\hline \multirow{3}{*}{$\begin{array}{c}\text { Nitrogen } \\
\text { rate } \\
\left(\mathrm{kg} \mathrm{ha}^{-1}\right) \\
\text { (A) }\end{array}$} & \multirow{3}{*}{$\begin{array}{l}\text { Iron } \\
\text { sources } \\
\text { (C) }\end{array}$} & \multicolumn{10}{|c|}{ Phosphorus rate $\left(\mathrm{Kg} \mathrm{ha}^{-1}\right)(\mathrm{B})$} \\
\hline & & $\mathbf{0}$ & 15 & 31 & 47 & Mean & $\mathbf{0}$ & 15 & 31 & 47 & Mean \\
\hline & & \multicolumn{5}{|c|}{ Grain } & \multicolumn{5}{|c|}{ Straw } \\
\hline \multirow{3}{*}{190} & Without & 10.33 & 13.47 & 15.87 & 12.69 & 13.09 & 3.05 & 3.65 & 5.06 & 5.05 & 4.20 \\
\hline & Min.Fe & 11.23 & 13.26 & 23.39 & 18.18 & 16.52 & 2.76 & 4.33 & 6.82 & 5.93 & 4.96 \\
\hline & Chel.Fe & 9.08 & 14.44 & 21.78 & 12.67 & 14.49 & 3.76 & 4.03 & 7.30 & 3.89 & 4.74 \\
\hline \multicolumn{2}{|c|}{ Mean } & 10.21 & 13.72 & 20.35 & 14.51 & 14.70 & 3.19 & 4.00 & 6.39 & 4.95 & 4.64 \\
\hline \multirow{3}{*}{285} & Without & 9.47 & 11.07 & 15.35 & 11.67 & 11.89 & 3.80 & 3.76 & 5.25 & 4.91 & 4.43 \\
\hline & Min.Fe & 12.94 & 15.99 & 16.40 & 21.90 & 16.81 & 5.60 & 5.57 & 9.17 & 7.23 & 6.89 \\
\hline & Chel.Fe & 14.06 & 16.40 & 21.97 & 19.00 & 17.86 & 6.53 & 4.68 & 11.64 & 7.44 & 7.57 \\
\hline \multicolumn{2}{|c|}{ Mean } & 12.16 & 14.49 & 17.90 & 17.52 & 15.52 & 5.31 & 4.67 & 8.69 & 6.53 & 6.30 \\
\hline & Without & 11.35 & 14.26 & 16.74 & 15.18 & 14.38 & 4.19 & 3.91 & 8.79 & 5.51 & 5.60 \\
\hline \multirow[t]{2}{*}{380} & Min.Fe & 14.81 & 16.16 & 25.46 & 24.99 & 20.36 & 4.12 & 5.46 & 8.24 & 9.64 & 6.87 \\
\hline & Chel.Fe & 16.67 & 16.55 & 25.25 & 22.22 & 20.17 & 4.43 & 6.29 & 8.53 & 7.65 & 6.73 \\
\hline \multirow{2}{*}{\multicolumn{2}{|c|}{ Mean }} & 14.28 & 15.65 & 22.48 & 20.80 & 18.30 & 4.25 & 5.22 & 8.52 & 7.60 & 6.40 \\
\hline & & \multicolumn{10}{|c|}{ Mean of Fe treatment } \\
\hline & Without & 10.38 & 12.93 & 15.98 & 13.18 & 13.12 & 3.68 & 3.77 & 6.37 & 5.16 & 4.75 \\
\hline & Min.Fe & 13.00 & 15.13 & 21.75 & 21.69 & 17.89 & 4.16 & 5.12 & 8.08 & 7.60 & 6.24 \\
\hline & Chel.Fe & 13.27 & 15.80 & 23.00 & 17.96 & 17.51 & 4.91 & 5.00 & 9.16 & 6.33 & 6.35 \\
\hline \multirow{2}{*}{\multicolumn{2}{|c|}{ Mean }} & 12.22 & 14.62 & 20.24 & 17.61 & 16.17 & 4.25 & 4.63 & 7.87 & 6.36 & 5.78 \\
\hline & & \multicolumn{2}{|c|}{$A=0.581$} & \multicolumn{2}{|c|}{$\mathrm{AB}=1.09$} & & \multicolumn{2}{|c|}{$\mathrm{A}=0.193$} & \multicolumn{3}{|c|}{$\mathrm{AB}=0.429$} \\
\hline \multirow{3}{*}{\multicolumn{2}{|c|}{$\begin{array}{c}\text { LSD } \\
(\mathbf{0 . 0 5})\end{array}$}} & \multicolumn{2}{|c|}{$B=0.632$} & \multicolumn{2}{|c|}{$\mathrm{BC}=1.24$} & & \multicolumn{2}{|c|}{$B=0.248$} & \multicolumn{3}{|c|}{$\mathrm{BC}=0.548$} \\
\hline & & \multirow{2}{*}{\multicolumn{2}{|c|}{$\begin{array}{l}\mathrm{C}=0.618 \\
\mathrm{ABC}=2.143\end{array}$}} & $\mathrm{AC}=$ & & & \multirow{2}{*}{\multicolumn{2}{|c|}{$\begin{array}{l}\mathrm{C}=0.274 \\
\mathrm{ABC}=0.950\end{array}$}} & \multirow{2}{*}{\multicolumn{3}{|c|}{$\mathrm{AC}=0.476$}} \\
\hline & & & & & & & & & & & \\
\hline
\end{tabular}

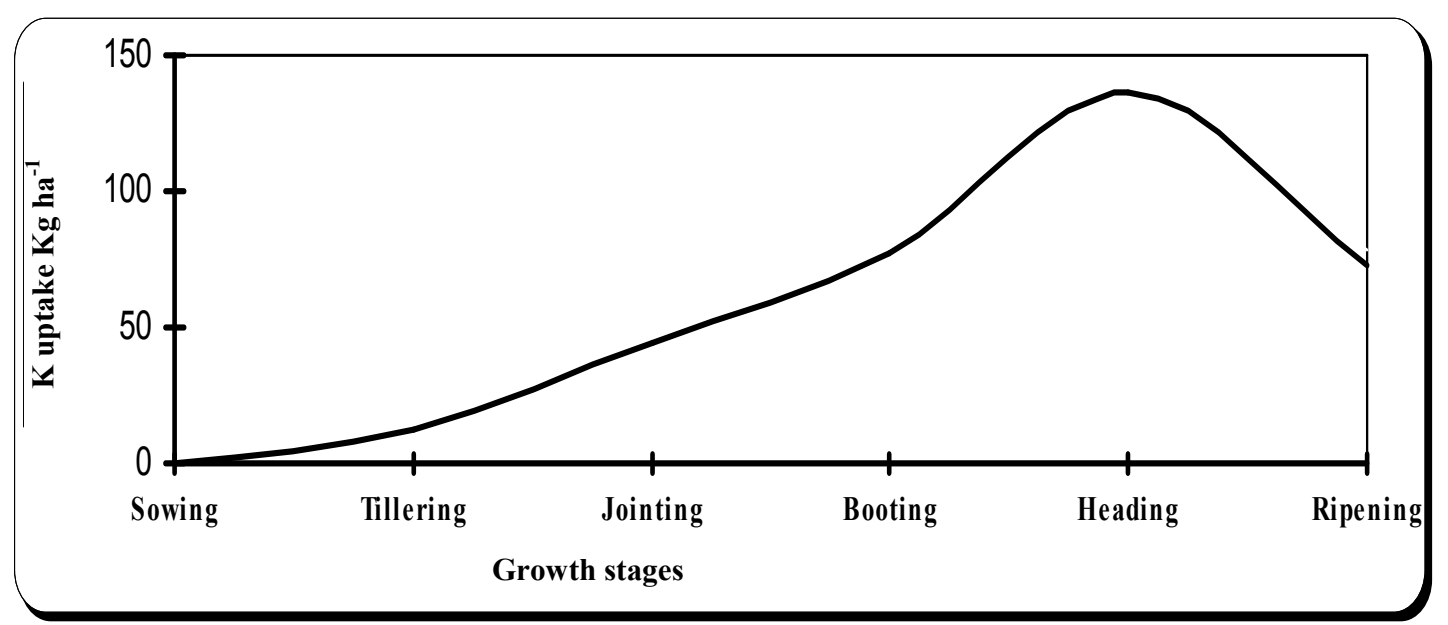

Fig. 4. Potassium uptake $\left(\mathrm{Kg} \mathrm{ha}^{-1}\right)$ at different growth stages 
Table 5. Grain and straw potassium uptake $\left(\mathrm{Kg} \mathrm{ha}^{-1}\right)$ as influenced by application of nitrogen, phosphorus fertilization and micronutrients foliar spray

\begin{tabular}{|c|c|c|c|c|c|c|c|c|c|c|c|}
\hline \multirow{3}{*}{$\begin{array}{c}\text { Nitrogen } \\
\text { rate } \\
\left(\mathrm{kg} \mathrm{ha}^{-1}\right) \\
\text { (A) }\end{array}$} & \multirow{3}{*}{$\begin{array}{c}\text { Iron } \\
\text { sources } \\
\text { (C) }\end{array}$} & \multicolumn{10}{|c|}{ Phosphorus rate $\left(\mathrm{Kg} \mathrm{ha}^{-1}\right)(\mathrm{B})$} \\
\hline & & $\mathbf{0}$ & 15 & 31 & 47 & Mean & $\mathbf{0}$ & 15 & 31 & 47 & Mean \\
\hline & & \multicolumn{5}{|c|}{ Grain } & \multicolumn{5}{|c|}{ Straw } \\
\hline & Without & 9.45 & 12.30 & 14.74 & 15.01 & 12.87 & 27.69 & 24.55 & 47.24 & 47.82 & 36.82 \\
\hline \multirow[t]{2}{*}{190} & Min.Fe & 10.49 & 13.45 & 19.14 & 16.82 & 14.98 & 37.69 & 44.05 & 51.52 & 42.62 & 43.97 \\
\hline & Chel.Fe & 8.54 & 12.84 & 15.12 & 12.91 & 12.35 & 32.65 & 18.60 & 60.67 & 50.76 & 40.67 \\
\hline \multicolumn{2}{|c|}{ Mean } & 9.49 & 12.86 & 16.33 & 14.91 & 13.40 & 32.68 & 29.07 & 53.14 & 47.07 & 40.49 \\
\hline \multirow{3}{*}{285} & Without & 10.02 & 11.47 & 16.03 & 12.54 & 12.51 & 41.91 & 43.56 & 64.43 & 45.30 & 48.80 \\
\hline & Min.Fe & 10.41 & 16.96 & 20.80 & 21.28 & 17.36 & 55.32 & 58.41 & 90.35 & 65.65 & 67.43 \\
\hline & Chel.Fe & 11.98 & 16.80 & 26.00 & 16.70 & 17.87 & 55.96 & 44.81 & 104.72 & 73.62 & 69.78 \\
\hline \multicolumn{2}{|c|}{ Mean } & 10.80 & 15.07 & 20.94 & 16.84 & 15.91 & 51.06 & 48.92 & 86.50 & 61.52 & 62.00 \\
\hline \multirow{3}{*}{380} & Without & 10.71 & 11.71 & 21.06 & 12.12 & 13.90 & 42.11 & 52.08 & 91.16 & 68.16 & 63.38 \\
\hline & Min.Fe & 8.53 & 17.34 & 22.56 & 31.42 & 19.96 & 52.64 & 67.26 & 91.20 & 71.69 & 70.70 \\
\hline & Chel.Fe & 13.61 & 16.15 & 21.70 & 19.64 & 17.77 & 30.77 & 77.17 & 102.20 & 93.76 & 75.97 \\
\hline \multicolumn{2}{|c|}{ Mean } & 10.95 & 15.07 & 21.77 & 21.06 & 17.21 & 41.84 & 65.50 & 94.85 & 77.87 & 70.02 \\
\hline & & \multicolumn{10}{|c|}{ Mean of Fe treatment } \\
\hline & Without & 10.06 & 11.83 & 17.28 & 13.22 & 13.10 & 37.24 & 40.06 & 67.61 & 53.76 & 49.67 \\
\hline & Min.Fe & 9.81 & 15.92 & 20.84 & 23.17 & 17.43 & 48.55 & 56.57 & 77.69 & 59.99 & 60.70 \\
\hline & Chel.Fe & 11.38 & 15.26 & 20.94 & 16.42 & 16.00 & 39.79 & 46.86 & 89.20 & 72.71 & 62.14 \\
\hline \multirow{2}{*}{\multicolumn{2}{|c|}{ Mean }} & 10.41 & 14.33 & 19.68 & 17.60 & 15.51 & 41.86 & 47.83 & 78.16 & 62.15 & 57.50 \\
\hline & & $\mathrm{A}=0.7$ & & $\mathrm{AB}=$ & $=0.836$ & & $\mathrm{~A}=1.59$ & & $\mathrm{AB}=2$ & 4.70 & \\
\hline \multirow{3}{*}{\multicolumn{2}{|c|}{$\begin{array}{c}\text { LSD } \\
(\mathbf{0 . 0 5})\end{array}$}} & \multicolumn{2}{|c|}{$\mathrm{B}=0.483$} & \multicolumn{3}{|c|}{$\mathrm{BC}=0.994$} & \multicolumn{2}{|c|}{$\mathrm{B}=2.71$} & \multicolumn{3}{|c|}{$\mathrm{BC}=3.87$} \\
\hline & & \multicolumn{2}{|c|}{$\mathrm{C}=0.497$} & \multicolumn{3}{|c|}{$\mathrm{AC}=0.861$} & \multicolumn{2}{|c|}{$\mathrm{C}=1.93$} & \multicolumn{3}{|c|}{$\mathrm{AC}=3.35$} \\
\hline & & \multicolumn{5}{|c|}{$\mathrm{ABC}=1.72$} & \multicolumn{5}{|c|}{$\mathrm{ABC}=6.69$} \\
\hline
\end{tabular}


Table 6. Grain and straw iron uptake $\left(\mathrm{Kg} \mathrm{ha}^{-1}\right)$ as influenced by application of nitrogen, phosphorus fertilization and micronutrients foliar spray

\begin{tabular}{|c|c|c|c|c|c|c|c|c|c|c|c|}
\hline \multirow{2}{*}{$\begin{array}{c}\text { Nitrogen } \\
\text { rate } \\
\left(\mathrm{kg} \mathrm{ha}^{-1}\right) \\
(\mathrm{A})\end{array}$} & \multirow{2}{*}{$\begin{array}{c}\text { Iron } \\
\text { sources } \\
\text { (C) }\end{array}$} & \multicolumn{10}{|c|}{ Phosphorus rate $\left(\mathrm{Kg} \mathrm{ha}^{-1}\right)(\mathrm{B})$} \\
\hline & & $\mathbf{0}$ & 15 & 31 & 47 & Mean & $\mathbf{0}$ & 15 & 31 & 47 & Mean \\
\hline & & \multicolumn{5}{|c|}{ Grain } & \multicolumn{5}{|c|}{ Straw } \\
\hline \multirow{3}{*}{190} & Without & 0.02 & 0.04 & 0.08 & 0.06 & 0.05 & 0.06 & 0.17 & 0.30 & 0.24 & 0.20 \\
\hline & Min.Fe & 0.12 & 0.24 & 0.48 & 0.37 & 0.30 & 0.46 & 0.94 & 1.34 & 1.09 & 0.96 \\
\hline & Chel.Fe & 0.07 & 0.20 & 0.36 & 0.27 & 0.22 & 0.41 & 0.73 & 1.44 & 1.04 & 0.90 \\
\hline \multicolumn{2}{|c|}{ Mean } & 0.07 & 0.16 & 0.31 & 0.24 & 0.19 & 0.31 & 0.61 & 1.03 & 0.79 & 0.69 \\
\hline \multirow{3}{*}{285} & Without & 0.04 & 0.06 & 0.13 & 0.09 & 0.08 & 0.17 & 0.20 & 0.37 & 0.33 & 0.27 \\
\hline & Min.Fe & 0.35 & 0.54 & 0.80 & 0.60 & 0.57 & 1.03 & 1.62 & 2.53 & 1.91 & 1.77 \\
\hline & Chel.Fe & 0.37 & 0.48 & 0.79 & 0.54 & 0.55 & 0.97 & 1.57 & 2.41 & 1.95 & 1.73 \\
\hline \multicolumn{2}{|c|}{ Mean } & 0.26 & 0.36 & 0.57 & 0.41 & 0.40 & 0.72 & 1.13 & 1.77 & 1.40 & 1.25 \\
\hline \multirow{4}{*}{380} & Without & 0.04 & 0.05 & 0.11 & 0.08 & 0.07 & 0.10 & 0.19 & 0.46 & 0.32 & 0.27 \\
\hline & Min.Fe & 0.20 & 0.32 & 0.64 & 0.53 & 0.42 & 0.81 & 1.51 & 2.20 & 1.84 & 1.59 \\
\hline & Chel.Fe & 0.22 & 0.29 & 0.44 & 0.35 & 0.33 & 0.72 & 1.03 & 1.68 & 1.43 & 1.22 \\
\hline & & 0.15 & 0.22 & 0.40 & 0.32 & 0.27 & 0.54 & 0.91 & 1.45 & 1.19 & 1.03 \\
\hline & & \multicolumn{10}{|c|}{ Mean of Fe treatment } \\
\hline & Without & 0.03 & 0.05 & 0.11 & 0.08 & 0.07 & 0.11 & 0.19 & 0.38 & 0.30 & 0.24 \\
\hline & Min.Fe & 0.22 & 0.37 & 0.64 & 0.50 & 0.43 & 0.77 & 1.36 & 2.02 & 1.61 & 1.44 \\
\hline & Chel.Fe & 0.22 & 0.32 & 0.53 & 0.39 & 0.37 & 0.70 & 1.11 & 1.85 & 1.47 & 1.28 \\
\hline \multirow{2}{*}{\multicolumn{2}{|c|}{ Mean }} & 0.16 & 0.25 & 0.43 & 0.32 & 0.29 & 0.52 & 0.89 & 1.42 & 1.13 & 0.99 \\
\hline & & \multicolumn{2}{|c|}{$\mathrm{A}=0.049$} & \multicolumn{3}{|c|}{$\mathrm{AB}=\mathrm{ns}$} & \multicolumn{2}{|c|}{$\mathrm{A}=0.088$} & \multicolumn{3}{|c|}{$\mathrm{AB}=0.091$} \\
\hline \multirow{3}{*}{\multicolumn{2}{|c|}{$\begin{array}{c}\text { LSD } \\
(\mathbf{0 . 0 5})\end{array}$}} & \multicolumn{2}{|c|}{$\mathrm{B}=0.036$} & \multirow{2}{*}{\multicolumn{3}{|c|}{$\begin{array}{l}\mathrm{BC}=0.066 \\
\mathrm{AC}=0.057\end{array}$}} & \multicolumn{2}{|c|}{$\mathrm{B}=0.053$} & \multicolumn{3}{|c|}{$\mathrm{BC}=0.10$} \\
\hline & & \multirow{2}{*}{\multicolumn{2}{|c|}{$\mathrm{ABC}=\mathrm{ns}$}} & & & & $\mathrm{C}=0 . \mathrm{C}$ & & $\mathrm{AC}=$ & 0.090 & \\
\hline & & & & & & & \multicolumn{2}{|c|}{$\mathrm{ABC}=0.181$} & & & \\
\hline
\end{tabular}

The straw iron uptake by wheat ranged between 0.06 and $2.53 \mathrm{Kg} \mathrm{ha}^{-1}$. The lowest was obtained by $190 \mathrm{Kg} \mathrm{N} \mathrm{ha}{ }^{-1}$. The highest was obtained by $285 \mathrm{Kg} \mathrm{N}^{-1}+31 \mathrm{Kg} \mathrm{P} \mathrm{ha}^{-1}+$ mineral iron. For nitrogen addition, the results indicated that increasing nitrogen addition from 190 to 285 or $380 \mathrm{Kg} \mathrm{N} \mathrm{ha}^{-1}$ increased straw iron uptake by averages of 81.2 and $49.3 \%$, respectively. For phosphorus addition, the results indicated that increasing phosphorus addition from 0 to 15,31 or $47 \mathrm{Kg} \mathrm{P} \mathrm{ha}{ }^{-1}$ increased straw iron uptake by averages of 71 , 173 and $117 \%$, respectively.

Iron spray treatments showed that mineral iron spray and chelated iron increased iron uptake by 500 and $533 \%$, respectively. This indicates that iron plays important plant functions. These agree with findings reported by (Pervaiz et al., 2003; Eskandari, 2011; Havlin et al., 2014).

\section{Some Chemical Properties of Soil}

Results in Table 7 show that addition of ammonium sulphate decreased soil $\mathrm{pH}$, while increased soil EC. The $\mathrm{pH}$ values in the $2^{\text {nd }}$ depth $(30-60 \mathrm{~cm})$ were higher than those found in the $1^{\text {st }}$ depth $(0-30 \mathrm{~cm})$. Increased application of superphosphate led to decreased soil $\mathrm{pH}$, while increased EC. Increased application of ammonium sulphat and superphosphate increased the extractable amounts of N, P and K. These results agree with Lyamuremye et al. (1996), 
Table 7. Effect of nitrogen and phosphorus fertilization and iron on some chemical characteristics in soil after harvesting wheat

\begin{tabular}{|c|c|c|c|c|c|c|c|c|c|c|c|}
\hline \multirow{3}{*}{\multicolumn{2}{|c|}{$\begin{array}{l}\text { Nitrogen Phosphorus } \\
\text { rates rates } \\
\mathrm{Kg} \mathrm{ha}^{-1} \mathrm{Kg} \mathrm{ha}^{-1}\end{array}$}} & \multicolumn{5}{|c|}{$0-30 \mathrm{~cm}$} & \multicolumn{5}{|c|}{$30-60 \mathrm{~cm}$} \\
\hline & & \multicolumn{2}{|c|}{$(1: 5)$ Ext. } & \multicolumn{3}{|c|}{ Available } & \multicolumn{2}{|c|}{ (1:5) Ext. } & \multicolumn{3}{|c|}{ Available } \\
\hline & & pH & $\mathrm{EC} \mathrm{dSm}^{-1}$ & $\mathbf{N}$ & $\mathbf{P}$ & $\mathbf{K}$ & $\overline{p H}$ & $\mathrm{EC} \mathrm{dSm}^{-1}$ & $\overline{\mathbf{N}}$ & $\overline{\mathbf{P}}$ & $\mathbf{K}$ \\
\hline \multirow{4}{*}{190} & $\mathbf{0}$ & 8.06 & 0.31 & 42 & 6.87 & 65.6 & & 0.10 & 28 & 3.96 & 46.0 \\
\hline & 15 & 8.05 & 0.32 & 42 & 7.53 & 211.6 & 8.41 & 0.12 & 28 & 6.72 & 48.8 \\
\hline & 31 & 8.04 & 0.32 & 42 & 7.86 & 131.2 & 8.35 & 0.13 & 35 & 9.78 & 50.8 \\
\hline & 47 & 7.83 & 0.34 & 49 & 9.12 & 131.2 & 8.37 & 0.13 & 42 & 9.96 & 51.4 \\
\hline \multirow{4}{*}{285} & $\mathbf{0}$ & 7.89 & 0.35 & 56 & 9.96 & 132.4 & 8.06 & 0.13 & 42 & 3.48 & 55.4 \\
\hline & 15 & 7.89 & 0.35 & 70 & 10.56 & 216.8 & 8.55 & 0.14 & 49 & 8.25 & 56.6 \\
\hline & 31 & 7.94 & 0.36 & 70 & 11.07 & 207.0 & 8.26 & 0.14 & 49 & 9.81 & 55.8 \\
\hline & 47 & 7.94 & 0.39 & 84 & 13.92 & 254.6 & 8.26 & 0.14 & 56 & 10.98 & 58.4 \\
\hline \multirow{4}{*}{380} & $\mathbf{0}$ & 7.83 & 0.44 & 91 & 8.88 & 221.6 & 8.13 & 0.18 & 56 & 4.11 & 59.2 \\
\hline & 15 & 7.84 & 0.44 & 98 & 10.83 & 247.8 & 7.95 & 0.21 & 77 & 5.85 & 59.6 \\
\hline & 31 & 7.98 & 0.52 & 112 & 11.43 & 216.8 & 7.92 & 0.20 & 91 & 7.14 & 97.6 \\
\hline & 47 & 7.94 & 0.44 & 126 & 12.09 & 220.2 & 7.98 & 0.24 & 98 & 9.39 & 72.0 \\
\hline
\end{tabular}

Stuart and Sumner (1997), Gaber and Dahdoh (1999), Zebarth et al. (1999) and El-Maghraby (2002).

\section{Conclusion}

Results indicates that the application of treatment $285 \mathrm{Kg} \mathrm{N}+31 \mathrm{P} \mathrm{ha}^{-1}$ and chelated iron was giving the highest value for each of grain and straw yields at 4.81 and $9.15 \mathrm{Mg} \mathrm{ha}^{-1}$, respectively.

\section{REFERENCES}

Betric, B., Z. Loncaric, V. Vukadinovic, M. Vukobratovic, Z. Vukobratovic and T. Teklic (2006). Cereal yield responses to mineral fertilization. Fac. Agric., Univ. J.J. Strossmayer in Osijek, Trg. Sv. Cereal Res. Commun., 34 (1): 405-408.

Black, C.A., D.D. Evans, J.L. White, L.E. Ensminger and F.E. Clark (1965). Methods of Soil Analysis. Ame. Soc. Agron. Inc., Madison, WI, USA.
Bremner, D.C. and J.M. Mulvaney (1982). Total Nitrogen. In:Methods of Soil Analysis. A. L. Page, R. H. Miller and D. R. Keaney, Eds). Number 9 Part 2, Ame. Soc. Agron. Inc. Madison WI, USA.

Chapman, H.D. and P.F. Pratt (1961). Methods of Analysis for Soils, Plants and Water. Div. Agric. Sci. Univ. Calif. USA.

El-Maghraby, S.E. (2002). Influence of tillage depth and organic residue placement on calcareous soil productivity under irrigation frequencies with high saline water. Egypt. J. App. Sci., 17(2): 331-349.

Eskandari, H. (2011). The importance of iron $(\mathrm{Fe})$ in plant products and mechanism of its uptake by plants. J. Appl. Environ. Biol. Sci. 1 (10): 448-452.

Gaber, A.M. and M.S.A. Dahdoh (1999). Response of barley to organic wastes and water stress under irrigation with saline water. Des. Inst. Bull., Egypt, 49 (2): 219-242. 
Grant, C.A., D.N. Flaten, D.J. Tomasiewicz and S.C. Sheppard (2001). The importance of early season phosphorus nutrition. Canadian J. Plant Sci., 81: 211-224.

Grundon, N.J., D.G. Edwards, P.N. Takkar, C.J. Asher and R.B. Clark (1987). Nutrition disorders of grain sorghum ACIAR Monograph No. 2.

Havlin, J.L., S.L. Tisdale, W.L. Nelson and J.D. Beaton (2014). Soil fertility and nutrient management: An introduction to nutrient management. $8^{\text {th }}$ Ed. Pearson, Upper Saddle River, NJ, USA.

Holman, G.T. and G.L. Elliott (1983). Chemical Analysis of Ecological Materials. Lab. Proc., 32: 91-95.

Jamal, Z. and M.F. Chaudhary (2007). Effect of soil and foliar application of different concentrations of NPK and foliar application of $\left(\mathrm{NH}_{4}\right)_{2} \mathrm{SO}_{4}$ on growth and yield attributes in wheat (Triticum aestivum L.). Pak. J. P1. Sci., 13 (2) : 119-128.

Kegang, S. (2005). Nutrient limiting factors and balanced fertilization on high yield crops in Henan province. Soil and Fertilizer Inst., Henan Acad. Agric. Sci.China.

Khan, P., M.Y. Memo, M. Imtiaz and M. Aslam (2009). Response of wheat to foliar and soil application of urea at different growth stages. Pak. J. Bot., 41 (3): 1197-1204.

Lindsay, W.L. and W.A. Norvell (1978). Development of DTPA soil test for $\mathrm{Zn}, \mathrm{Fe}$ and $\mathrm{Cu}$. Soil Sci. Am. J., 42 : 421-428.
Lyamuremye, F., R.P. Dick and J. Bham (1996). Organic amendments and phosphorus dynamics: 1. phosphorus chemistry and sorption. Soil Sci., 7 : 429-435.

Olsen, S.R., C.V. Cole Watanabe and L.A. Dean (1954). Estimation of available phosphorus in soils by extraction with sodium bicarbonate. (USDA. Circ. 939) Washington, DC, USA.

Pervaiz, Z., K. Hussain, S.S.H. Kazmi, K.H. Gill and A.A. Sheikh (2003). Iron requirement of Barani wheat. Int. J. Agri. Biol., 5 (4) : 608610.

Silwana, T.T., E.O. Lucas, and A.B. Olaniyan (2007). The effect of inorganic and organic fertilizers on growth and development of component crops in maize/beab intercrop in Eastren Cape of South Afr. J. Fd. Agric. and Environ., 5 (1): 267-272.

Sturat, P. and M.E. Sumner (1997). Cations and nitrogen contents of organic matter determine its soil liming potential. Soil Sci. Soc. Am. J., 61:86 -92.

Thomas, R.L., R.W. Sheward and J.R. Mayer (1967). Comparison of conventional and automated procedures for nitrogen, phosphorus and potassium analysis of plant material using digestion. Agron. J., $59: 240$ 243.

Zebarth, B.J., G.H. Nelsen, E. Hogue and D. Neilsen (1999). Influence of organic waste amendments on selected soil physical and chemical properties. Can. J. Soil Sci., 79 : $501-504$. 


\section{تأثير التسميد بالتيتروجين والفوسفور والحديد على الإنتاجية والمحتوى المعني للامح

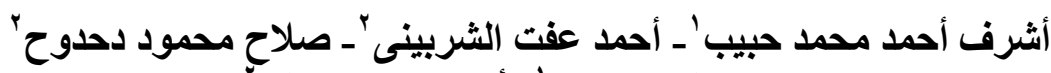

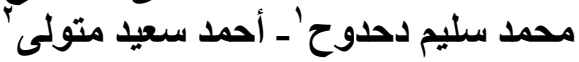 \\ ـ قسم خصوبة ومبكروبيولوجيا الأر اضي ـ مركز بحوث الصحر اء ـ المطرية ـ القاهرة- مصر \\ r ـ قسم علوم الأر اضي ـ كلية الزراعة ـ جامعة الزقازيق - مصر}

أجريت هذه الدراسة على محصول القمح بمحطة بحوث القنطرة شرق التابعة لمركز بحوث الصحر اء، خلال موسم

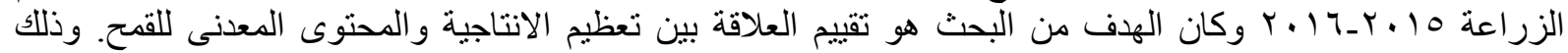

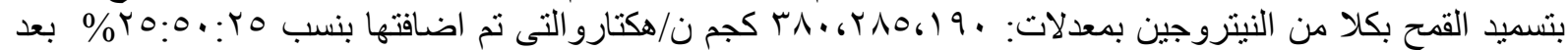

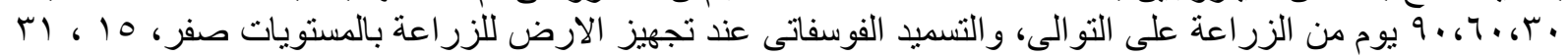

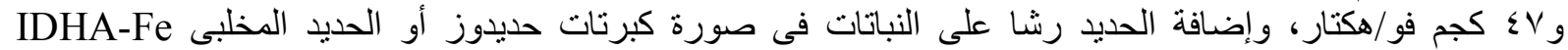

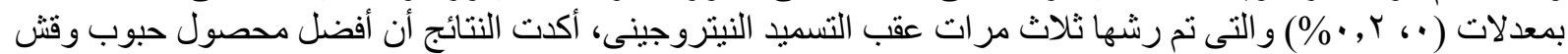

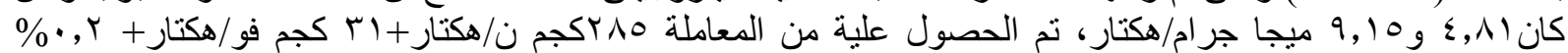

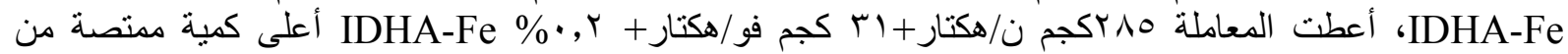

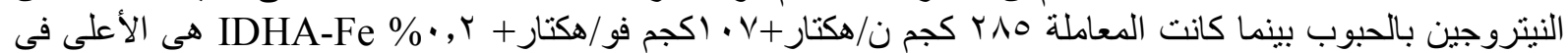

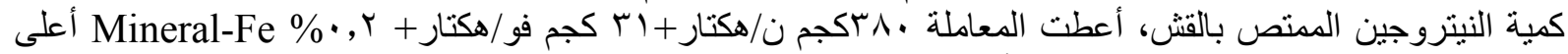

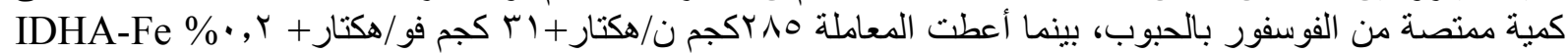

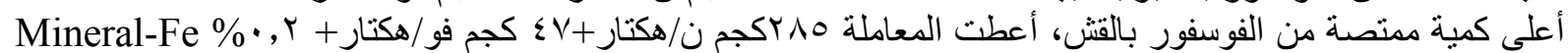

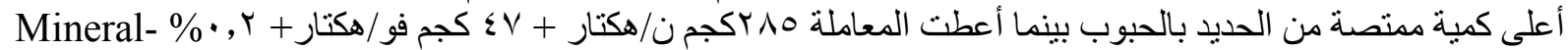
Fe

أستاذ الأر اضي المتفرغ - كلية الزر اعة بمشتهر - جامعة بنها. أستاذ الأر اضي - كلية الزر اعة - جامعة الز قازيق. 